\title{
Empirical Study of e-Procurement Adoption in Thailand
}

\author{
Siwaporn Kunnapapdeelert ${ }^{1 *}$, Sirintorn Thepmongkorn ${ }^{2}$ \\ ${ }_{1}^{1}$ Department of Logistics Management, Burapha University International College, Bangsean, Chonburi, \\ Thailand. \\ ${ }^{2}$ Department of Management, Burapha University International College, Bangsean, Chonburi, Thailand. \\ * Corresponding author. Tel.: +66 (64) 1599245; email: siwapornk@go.buu.ac.th \\ Manuscript submitted April 20, 2017, accepted June 2, 2017. \\ doi: 10.17706/ijeeee.2017.7.4.246-254
}

\begin{abstract}
E-procurement is a very important system driving supply chain management to be more efficient. Purpose of thisstudy is to understand e-procurement adoption situation in Thailand and analyze critical success factor of e-procurement implementation. Readiness, benefits, barriers and critical success factors of e-procurement adoption in Thailand were analyzed as a starting point. Factor analysis was then applied to indicate the factor affecting the implementation of e-procurement in Thailand. The results showed that most of the companies are ready to use e-procurement in the future. However, some companies do not have idea about the benefits and barriers of e-procurement adoption. It was also found that four main factors affecting the e-procurement adoption are reliability of information technology and supplier performance, user acceptance of e-procurement systems, financial and integration of e-procurement systems, and top management support.
\end{abstract}

Key words: E-Procurement, barriers, benefits, logistics, factor analysis, supply chain management.

\section{Introduction}

Recently, supply chain management plays a very important role since various firms try to develop strategies for maintaining their competitiveness. Various organizations apply information \& communication technologies (ICT) to enhance supply chain operations [1]. E-procurement is one of the IT systems that used for automating the operations in supply chain. It is adopted to simplify and shorten procurement activities. E-procurement can help the organization to reduce the purchasing operational cost, paperwork, and the purchasing processes. Although, the developed countries in European and America regions have used the e-procurement in business transactions for many years, it has not been wildly used in Thailand yet.

For the last five years, many organizations in Thailand tried have to applied e-procurement. Traditionally, a procurement of raw materials or component parts has been performed through paper. When internet electronic commerce (e-commerce) was rapidly introduced in Thailand, the procurement was done through email and websites. Now some of the large companies have adopted e-procurement for purchasing of raw material, supplies, equipment, facility maintenance, and also the integration of all procurement processes (i.e. negotiation, manage the ordering, receipt, review and the approval of products from suppliers) [2]-[9]. Therefore, it is very interesting to study the adoption of e-procurement systems in Thailand for the successful integration of company's supply chain. The questionnaire based survey was designed for collecting the data related to the used of e-procurement technology and the potential influencing factors of 
e-procurement adoption in Thailand. The factor analysis was then applied for analyzing interrelationships among several numbers of variables that are highly interrelated.

\section{E-Procurement Adoption}

Electronic procurement (e-procurement) can be defined as the use of electronic communication to perform business process between sellers and buyer [2]. It is a powerful tool in business field for facilitating the acquisition of commodities through internet [3]. E-procurement focuses on main activities of purchasing operation such as supplier selection, defining the product requirement, negotiation and contracting with suppliers [4]. Although e-procurement is known to be the system that has several benefits for the organization, some of the organizations do not use such system. Those organizations might face some of the barriers when switching from the traditional procurement to the e-procurement.

\subsection{Readiness of the Organization to e-Procurement Adoption}

Technology have been developed and applied to several organizations to maintain their competitiveness. E-procurement is another IT system to improve processes in the procurement procedure. The successful implementation of e-procurement in organization needs to be supported by the top management team. The readiness for the adoption of e-procurement system would begin with the basic IT system to share information of the organization to other partner such as company's website. The website should provide general information of the product /service of the company and contain contact channel to the organization e.g. email or message box. Additionally, if the company website provides function for business transaction, it would be a big step for e-procurement adoption.

\subsection{Benefits of e-Procurement Adoption}

Benefits of e-procurement are described below [10]-[20].

Time reduction: The use of technologies can reduce the operational time of procurement process while increasing level of accuracy. The company can be successfully developed just in time concept (JIT) for reducing inventory level by using e-procurement.

Quick response to the problems: E-procurement is real time information that can reduce transaction time. Tracking and reporting of the status through real time information can help the partners in the supply chain to solve problems faster and more efficient.

Cost saving: E-procurement can reduce some activities which lead to the reduction of labor force. Further, the use of electronics can reduce unnecessary paper transaction, administrative and operational cost.

Enhancing supply chain efficiency: Providing real time information of product availability, inventory level, status of shipping and the production requirement can increase the efficiency of supply chain management.

\subsection{Barriers of e-Procurement Adoption}

Barriers of e-procurement adoptions are from both internal and external factors as follows. Internal factors [17], [21]:

Resources: The adoption of e-procurement in SME firms is not easy because their financial capital is quite limited. The SME firms need to be very careful when making the decision and taking risk for adopting e-procurement. Additionally, if the employees do not have technical expertise of procurement systems, it would be very hard for the organization to use e-procurement instead of the traditional procurement [5]-[7]. 
Organizational characteristics: The small organization might have limited budget so it would be difficult for the small organization to invest for e-procurement system. The adoption of e-procurement is found more in the larger firm especially the firm that have to contact to the international group and involve with the international trade [7].

External factors [9]:

Business partners: This factor is related to the incompatibility of the business partners (customers or suppliers). E-procurement adoption decision has high impact to the relationship between buyer-seller.

Technology does not compatible: There are risks related to the standard of e-procurement technologies. If the e-procurement used in their company does not widely accepted, it would prevent the integration of different e-procurement software across their supply chain.

Security of data: Company might fear about information access, exchange and disclosure of company's professionalism to the competitors. It is because there is a sharing of information among partner for e-procurement adoption.

\subsection{Critical Success Factors of e-Procurement Adoption}

Critical success factor for the adoption of e-procurement are reduce lead times, top management support, percentage of purchasing with accepted quality, productivity of resources (both human resources and information systems), budget accuracy and cost (including all the relevant cost categories, together with the cost of the purchased goods or services) [20]-[24].

\section{Research Methodology}

Main objective of this study is to understand current state of e-procurement adoption in Thailand and to examine the affect factors of e-procurement adoption in Thailand. The research questions are related to current status and readiness of the companies for e-procurement adoption, perceived benefits of e-procurement, perceived benefits of e-procurement, and critical success factors of e-procurement implementation. The study employed a cross-sectional field study survey approach. The data were collected from a survey of the companies in Thailand. 300 companies are randomly selected for the survey with the response of 40 replies. The questionnaire composes of four main sections. The first section seeks for the information of company including nature of business, size of company and existing technology. The second section focuses on the current status and readiness of company to implement the e-procurement. In the third section, the respondents were asked for rating perceived benefits of using e-procurement e.g. increased competitiveness, efficiency increment, value adding, improved customer satisfaction, etc. Section four focuses on the factors inhibiting e-procurement adoption. Respondents were asked to rate the reasons for not implementing e-procurement system in the organization. The critical success factors of e-procurement adoption such as centralize management of the procurement initiative, communication between participants, close collaboration with the suppliers, were asked to rate in section five. Lastly, the quantitative analysis was then conducted to the data based on factor analysis for analyzing critical success factors of e-procurement adoption.

\section{Results and Analysis}

The results for empirical analysis are discussed in this section. Respondents are from various areas as follows: automotive, banking, commerce, construction materials and services, electronics components, energy \& utilities, health care services, home \& office products, industrial materials \& machinery, information \& communication, technology, insurance, packaging, petrochemicals \& chemicals, property development, service, steel, tourism \& leisure, and transportation and logistics. Most of the respondents are 
from information and communication technology sector follow by transport and logistics sector and energy \& utilities, respectively. This implies that the respondents are diversified since various industry types are represented. The employee profiles are described in Table 1.

Table 1. Employee Profile of Respondent Companies

\begin{tabular}{|c|c|c|}
\hline & Frequency & Percentage \\
\hline \multicolumn{3}{|l|}{ Number of employee } \\
\hline Below 50 & 6 & 15 \\
\hline $50-199$ & 11 & 27.5 \\
\hline $200-499$ & 7 & 17.5 \\
\hline $500-999$ & 5 & 12.5 \\
\hline $1000-5000$ & 7 & 17.5 \\
\hline More than 5000 & 4 & 10 \\
\hline Total & 40 & 100 \\
\hline \multicolumn{3}{|l|}{ Number of purchasing staff } \\
\hline $1-5$ & 22 & 55 \\
\hline $6-10$ & 8 & 20 \\
\hline $11-15$ & 7 & 17.5 \\
\hline More than 15 & 3 & 7.5 \\
\hline Total & 40 & 100 \\
\hline \multicolumn{3}{|l|}{ Job position } \\
\hline Manager /Senior executive & 13 & 32.5 \\
\hline IT manager/Programmer/System & 6 & 15 \\
\hline Procurement officer & 4 & 10 \\
\hline Engineer & 4 & 10 \\
\hline Other & 13 & 32.5 \\
\hline Total & 40 & 100 \\
\hline \multicolumn{3}{|l|}{ Education level } \\
\hline Post-secondary certificate/diploma & 1 & 2.5 \\
\hline Bachelor's degree & 25 & 62.5 \\
\hline Master's degree or above & 14 & 35 \\
\hline Total & 40 & 100 \\
\hline \multicolumn{3}{|l|}{ Working Experience } \\
\hline Less than 3 years & 6 & 15 \\
\hline 3-6 years & 3 & 7.5 \\
\hline $7-10$ years & 12 & 30 \\
\hline 11-14 years & 16 & 40 \\
\hline More than 14 years & 3 & 7.5 \\
\hline Total & 40 & 100 \\
\hline
\end{tabular}

\subsection{Current Status and Readiness of Companies for e-Procurement Adoption}

The e-procurement adoption status and readiness of the company in Thailand are discussed in this section. The highlights percentage of ICT currently used in the company. Most companies (67\%) use LAN/intranet, 15\% use EBS while 13\% of the respondents use web-based application.

Percentages of the companies that have their own websites are described as $87 \%$ of the total respondents have their own website while $13 \%$ of the respondents do not have their own website. 
The information about how the companies use their website is presented that most of the company provide information about the company, information of product/service and industry information on the website. $80 \%$ of the companies provide support online ordering the product/service while $67.5 \%$ provide support online payment. $72.5 \%$ provide the contact information on their own website.

\subsection{Perceived Benefits of e-Procurement Implementation}

Perceived benefits of e-procurement implementation in Thailand are examined in this section. The respondents were asked to give the rating on a 5 points scale from strongly disagree to strongly agree as summarized in Table 2. Most of the respondents (more than 75\%) of the respondents) perceive that the adoption of e-procurement can increase competitiveness, improve supply chain integration, improve the company's image, increase customer service level, reduce operational tasks and reduce processing time. Overall, there is a very positive view about the implementation of e-procurement.

Table 2. Rating of Perceived Benefits to e-Procurement Adoption

\begin{tabular}{|c|c|c|c|c|c|c|c|}
\hline & Mean & SD & $\begin{array}{l}\text { Strongly } \\
\text { disagree }\end{array}$ & Disagree & Uncertain & Agree & $\begin{array}{c}\text { Strongly } \\
\text { agree }\end{array}$ \\
\hline Increase competitiveness & 4.13 & 0.81 & 0 & 1 & 8 & 16 & 15 \\
\hline Value adding & 3.90 & 0.83 & 0 & 2 & 10 & 18 & 10 \\
\hline Better supply chain integration & 3.90 & 0.92 & 1 & 2 & 7 & 20 & 10 \\
\hline Improve company's image & 4.20 & 0.87 & 0 & 2 & 6 & 14 & 18 \\
\hline Cost saving & 3.93 & 1.01 & 1 & 2 & 10 & 13 & 14 \\
\hline Reducing errors & 3.90 & 0.86 & 0 & 2 & 11 & 16 & 11 \\
\hline Increase customer service level & 4.25 & 0.83 & 0 & 1 & 7 & 13 & 19 \\
\hline Reduce inventory level & 3.70 & 0.90 & 0 & 4 & 12 & 16 & 8 \\
\hline Reduce operational tasks & 4.00 & 0.89 & 0 & 2 & 10 & 14 & 14 \\
\hline Reduce processing time & 4.15 & 0.79 & 0 & 1 & 7 & 17 & 15 \\
\hline Support environmental issues & 3.98 & 0.91 & 0 & 2 & 11 & 13 & 14 \\
\hline
\end{tabular}

\subsection{Perceived Barriers of e-Procurement Implementation}

The ratings of the barriers for implementing e-procurement in the organization are presented in Table 3. There is also 5 points scale for rating from strongly disagree to strongly agree. Majority of the companies believe that the reasons for not implementing e-procurement system in the companies are insufficient financial support, security concern, incompatible with ERP system, the company policy, lack of top management support and not the top priority of the company. Most of the respondents perceive that uncertainty and risk, inability to choose the appropriate IT technology, immaturity of technology and lack of skill and knowledge in e-procurement are not the main barrier of e-procurement implementation. However, there are some of the respondents that do not have idea about the barrier of e-procurement adoption.

Table 3. Rating of Perceived Barriers to e-Procurement Adoption

\begin{tabular}{|c|c|c|c|c|c|c|c|}
\hline & Mean & SD & $\begin{array}{l}\text { Strongly } \\
\text { disagree }\end{array}$ & Disagree & Uncertain & Agree & $\begin{array}{l}\text { Strongly } \\
\text { agree }\end{array}$ \\
\hline Insufficient financial support & 3.53 & 0.89 & 1 & 2 & 18 & 13 & 6 \\
\hline High maintenance cost & 3.33 & 0.82 & 1 & 2 & 24 & 9 & 4 \\
\hline Uncertainty and risk & 3.05 & 0.71 & 1 & 6 & 23 & 10 & 0 \\
\hline $\begin{array}{l}\text { Inability to select the appropriate } \\
\text { IT technology }\end{array}$ & 3.00 & 0.77 & 1 & 8 & 22 & 8 & 1 \\
\hline Security concern & 3.60 & 0.97 & 0 & 4 & 18 & 8 & 10 \\
\hline
\end{tabular}


Incompatible with ERP system

Customers not interested in the new service

Company's policy

Fear to change into a new system

Immaturity of technology

Lack of skill and knowledge in

e-procurement

Lack of top management support

Not the top priority of the company

$\begin{array}{lll}3.53 & 0.81 & 1 \\ 3.15 & 0.65 & 1 \\ 3.30 & 1.08 & 3 \\ 2.85 & 1.04 & 5 \\ 3.00 & 0.89 & 2 \\ 3.18 & 1.02 & 3 \\ 3.60 & 1.07 & 2 \\ 3.48 & 0.92 & 1\end{array}$

8

18

$\begin{array}{lcc}18 & 16 & 4 \\ 25 & 11 & 0 \\ 17 & 10 & 6 \\ 20 & 5 & 3 \\ 20 & 8 & 2 \\ 18 & 10 & 4 \\ 16 & 10 & 10 \\ 18 & 12 & 6\end{array}$

$\begin{array}{lcc}8 & 16 & 4 \\ 25 & 11 & 0 \\ 17 & 10 & 6 \\ 20 & 5 & 3 \\ 20 & 8 & 2 \\ 18 & 10 & 4 \\ 16 & 10 & 10 \\ 18 & 12 & 6\end{array}$

\subsection{Critical Success Factors of e-Procurement Adoption}

The ratings of critical success factor of e-procurement implementation are showed in Table 4. The respondents were asked to give the rating to the critical success factors of e- procurement implementation as 5-point scale questions from 1 being "strongly disagree" to 5 being "strongly agree". The results from the survey suggest that information management and information system specialists with internet skill are the most important factor for e-procurement adoption.

Table 4. Rating of Critical Success Factors for e-Procurement Implementation

\begin{tabular}{|c|c|c|c|c|c|c|c|}
\hline & Mean & SD & $\begin{array}{l}\text { Strongly } \\
\text { disagree }\end{array}$ & Disagree & Uncertain & Agree & $\begin{array}{c}\text { Strongly } \\
\text { agree }\end{array}$ \\
\hline $\begin{array}{l}\text { Centralized control and } \\
\text { management of e-procurement }\end{array}$ & 3.68 & 0.96 & 1 & 3 & 12 & 16 & 8 \\
\hline initiatives & & & & & & & \\
\hline $\begin{array}{l}\text { Communication between } \\
\text { participants }\end{array}$ & 3.83 & 0.74 & 0 & 1 & 12 & 20 & 7 \\
\hline $\begin{array}{l}\text { Clear and achievable } \\
\text { implementation phase }\end{array}$ & 3.88 & 0.78 & 0 & 1 & 12 & 18 & 9 \\
\hline $\begin{array}{l}\text { Close collaboration with the } \\
\text { suppliers }\end{array}$ & 3.63 & 0.86 & 0 & 3 & 16 & 14 & 7 \\
\hline Information management & 4.00 & 0.84 & 0 & 1 & 11 & 15 & 13 \\
\hline $\begin{array}{l}\text { Information systems specialists } \\
\text { with internet skill }\end{array}$ & 3.98 & 0.82 & 0 & 1 & 11 & 16 & 12 \\
\hline
\end{tabular}

The discussions in this section are the results from the survey on different aspects of companies and e-business adoption. Some of the questions seem to be closed to the critical success factor in e-procurement implementation. Therefore, the factor analysis was applied for analyzing the interrelationships among various variables that are highly interrelated. The results showed that there are four main factors that affect to the e-procurement adoption such as reliability of information technology and supplier performance, user acceptance of e-procurement systems, financial and integration of e-procurement systems, and top management support.

Considering the factor of reliability of information technology and supplier performance, this factor plays a vital role for the adoption of e-procurement. The reliable of IT system can reduce uncertainty and risk and enhance security of information which leads to the acceptance by the partners of the company. Therefore, the company should ensure that the IT system used in the company provides enough information, suitable for the company, easy to understand and secure. When any change on the system occurs, the supplier should be also joined for making the discussion. The procurement staffs should be well trained on the usage of e-procurement system for enhancing performance on the e-procurement implementation. 
The second factor is user acceptance of e-procurement systems. The acceptance of the system is considered as one of the most importance factor for e-procurement adoption. If the company has a positive attitude about e-procurement system, it would encourage the senior management to learn how to use the system, know how easy to incorporate other operation systems to the e-procurement and others benefits of e-procurement adoption. If the senior management can encourage employees to accept the e-procurement system, the e-procurement can be successfully implemented.

The next factor is financial and integration of e-procurement systems. Financial support is another essential factor to e-procurement adoption. It challenges the organization to make the decision on changing the system since there are investing cost and maintenance cost involved. It is very important to educate partners of the company about benefits of e-procurement implementation, the use of e-procurement system, and how to select the system that compatible to their current systems. These will enable all organization in the supply chain to implement e-procurement successfully.

The last factor is top management support. It is the main factor that affect to the decision of the e-procurement adoption. The smaller organization has lesser opportunity to implementing e-procurement because it has limit budget. However, if the top management have a positive attitude about the use of e-procurement, it would be easier to implement e-procurement in their organization.

\section{Conclusion and Recommendations}

Current trend in current industry is the use of information technology. E-procurement becomes famous in the last decade especially in developed countries. Although, the use of e-procurement has a lot of benefits, some companies do not want to use e-procurement. Consequently, the study of readiness, perceived benefits, barriers, and critical success factor of e-procurement implementation of developing country as Thailand are needed. The results indicate that some of the respondents know benefits and barriers of e-procurement adoption but the companies are not ready to adopt e-procurement yet. The critical success factor for e-procurement implementation are reliability of information technology and supplier performance, user acceptance of e-procurement systems, financial and user acceptance of e-procurement systems, and top management support. The organization in Thailand especially top management levels still need to be educated about benefits of e-procurement adoption, how to use and integrate the e-procurement to the existing systems which would encourage Thai organization to implement e-procurement. It is recommended that the study of e-procurement adoption be further analyzed by more advance techniques as structural equation modeling (SEM) to establish more detailed interrelationship among variable of e-procurement adoption.

\section{References}

[1] Chung, P., Yeh, R. C., \& Chen, Y. C. (2015). Implementation of e-logistics systems for developing EC capability in small and medium-sized enterprises: A conceptual model. International Journal of e-Education, e-Business, e-Management and e-Learning, 5(4), 203.

[2] Alvarez-Rodríguez, J. M., Labra-Gayo, J. E., \& Pablos, P. O. (2014). New trends on e-procurement applying semantic technologies: Current status and future challenges. Computers in Industry, 65(5), 800-820.

[3] Barua, A., Konana, P., Whinston, A. B., \& Yin, F. (2001). Driving e-business excellence. MIT Sloan 
Management Review, 43(1), 36.

[4] Lancioni, R., Schau, H. J., \& Smith, M. F. (2003). Internet impacts on supply chain management. Industrial Marketing Management, 32(3), 173-175.

[5] Stockdale, R., \& Standing, C. (2004). Benefits and barriers of electronic marketplace participation: an SME perspective. Journal of Enterprise Information Management, 17(4), 301-311.

[6] Ongori, H., \& Migiro, S. O. (2010). Information and communication technologies adoption in SMEs: literature review. Journal of Chinese Entrepreneurship, 2(1), 93-104.

[7] Karjalainen, K., \& Kemppainen, K. (2008). The involvement of small-and medium-sized enterprises in public procurement: Impact of resource perceptions, electronic systems and enterprise size. Journal of Purchasing and Supply Management, 14(4), 230-240.

[8] Johnson, M. (2010). Barriers to innovation adoption: a study of e-markets. Industrial Management \& Data Systems, 110(2), 157-174.

[9] Davila, A., Gupta, M., \& Palmer, R. (2003). Moving procurement systems to the internet: The adoption and use of e-procurement technology models. European management journal, 21(1), 11-23.

[10] Min, H., \& Galle, W. P. (2003). E-purchasing: Profiles of adopters and nonadopters. Industrial Marketing Management, 32(3), 227-233.

[11] Teo, T. S., Lin, S., \& Lai, K. H. (2009). Adopters and non-adopters of e-procurement in Singapore: An empirical study. Omega, 37(5), 972-987.

[12] Chang, H. H., \& Wong, K. H. (2010). Adoption of e-procurement and participation of e-marketplace on firm performance: Trust as a moderator. Information \& Management, 47(5), 262-270.

[13] Toktaş-Palut, P., Baylav, E., Teoman, S., \& Altunbey, M. (2014). The impact of barriers and benefits of e-procurement on its adoption decision: An empirical analysis. International Journal of Production Economics, 158, 77-90.

[14] Gunasekaran, A., \& Ngai, E. W. (2008). Adoption of e-procurement in Hong Kong: An empirical research. International Journal of Production Economics, 113(1), 159-175.

[15] Directorate-General, E. C. I. M. (2010). Study on the evaluation of the Action Plan for the implementation of the legal framework for electronic procurement (Phase II). Analysis, Assessment and Recommendation.

[16] Eei, K. S., Husain, W., \& Mustaffa, N. (2012). Survey on benefits and barriers of e-procurement: Malaysian SMEs perspective. International Journal on Advanced Science, Engineering and Information Technology, 2(6), 424-429.

[17] Latif, F. Ö. B. (2014). The adoption of electronic procurement in Turkey. Advances in Economics and Business, 2(2), 85-91.

[18] Vaidyanathan, G., \& Devaraj, S. (2008). The role of quality in e-procurement performance: An empirical analysis. Journal of Operations Management, 26(3), 407-425.

[19] Batenburg, R. (2007). E-procurement adoption by European firms: A quantitative analysis. Journal of Purchasing and Supply Management, 13(3), 182-192.

[20] Panayiotou, N. A., Gayialis, S. P., \& Tatsiopoulos, I. P. (2004). An e-procurement system for governmental purchasing. International Journal of Production Economics, 90(1), 79-102.

[21] Hawking, P., Stein, A., Wyld, D. C., \& Foster, S. (2004). E-procurement: Is the ugly duckling actually a 
swan down under? Asia Pacific Journal of Marketing and Logistics, 16(1), 3-26.

[22] Vaidya, K., Sajeev, A. S. M., \& Callender, G. (2004, April). E-Procurement initiatives in the public sector: An investigation into the critical success. Proceedings of 13th Annual International Purchasing \& Supply Education \& Research Association (IPSERA) Conference (pp. 4-7).

[23] Leipold, K., Klemow, J., Holloway, F., \& Vaidya, K. (2004). The world bank e-procurement for the selection of consultants: Challenges and lessons learned. Journal of Public Procurement, 4(3), 319.

[24] Alshaher, A. A. F. (2015). Exploratory study in critical success factors for e-management implementation success in Al-hukama firm for producing drugs and medical requirements. International Journal of e-Education, e-Business, e-Management and e-Learning, 5(1), 13.

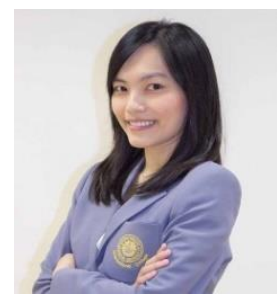

Siwaporn Kunnapapdeelert is a lecturer in Burapha University, International College. She held a doctoral degree in industrial engineering and management at the Asian Institute of Technology. She held a master of engineering in industrial engineering and management from Sirindhorn International Institute of Technology. Her research interest is in supply chain and logistic systems.

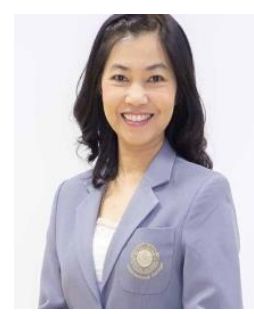

Sirintorn Thepmongkorn has been the associate dean for global affairs of Burapha University International College (BUUIC), Thailand for two years. Sirintorn earned her undergraduate degree in English business communication from Sripatum University in Bangkok, she also received a scholarship from Mahanakorn University of Technology for her master degree in technology management from the University of New South Wales in Sydney, Australia. Sirintorn was working at Mahanakorn University of Technology for six years. Her work experienced was head of Department, Department of Industrial Management, Faculty of Business Administration. Sirintorn has started work at Burapha University International College (BUUIC) since 2007. Prior to becoming the Associate Dean of BUUIC, Sirintorn was the Assistant Dean for Academic Affairs for a year and seven years as Chairperson of B.B.A. Program. She has been served at BUUIC where she leads the team for Double Degree Program and Exchange Program and be part of curriculum team for teaching and learning at BUUIC. Her research interests are in the area of human resource management. 